Abstract

\title{
The Effect of Gilaburu (Viburnum opulus) Juice on Ehrlich Ascites Tumor (EAT) Cell Culture ${ }^{+}$
}

\author{
Özge Al 1,*, Harun Ülger ${ }^{1}$, Tolga Eetekin ${ }^{2}$, Mehtap Nisari ${ }^{1}$, Hatice Susar ${ }^{1}$, Dilek Ceylan ${ }^{3}$ and \\ Gökçe Şeker Karatoprak ${ }^{4}$ \\ 1 Department of Anatomy, Faculty of Medicine, Erciyes University, Kayseri 38039, Turkey; \\ ulger@erciyes.edu.tr (H.U.); mehtaph@erciyes.edu.tr (M.N); hsusar@erciyes.edu.tr (H.S.) \\ 2 Department of Anatomy, Faculty of Medicine, Afyon Kocatepe University, Afyon 03200, Turkey; \\ tolga.ertekin@yahoo.com \\ 3 Betül-Ziya EREN Genom ve Stem Cell Centre, Erciyes Üniversitesi, Kayseri 38039, Turkey; \\ dlkceylan@gmail.com \\ 4 Department of Pharmacognocy, Faculty of Pharmacy, Erciyes Üniversitesi, Kayseri 38039, Turkey; \\ gskaratoprak@erciyes.edu.tr \\ * Correspondence: ozgeal@erciyes.edu.tr; Tel.: +095343535591 \\ + Presented at the 2nd International Conference on Natural Products for Cancer Prevention and Therapy, \\ Kayseri, Turkey, 8-11 November 2017.
}

Published: 15 November 2017

\begin{abstract}
Cancer is a significant public health problem in both developed and developing countries. Phytotherapy studies have gained importance due to the side effect of standard cancer therapy protocols. Viburnum opulus, belongs to the Caprifoliaceae family, is used in the treatment of various diseases. Anticarcinogenic effects of Viburnum opulus have also been reported. The aim of this study is to compare the cytotoxic effect of Gilaburu juice extract given at various doses against EAT cell in culture. The juice of the fermented Gilaburu fruit were centrifuged filtered through a $50 \mathrm{kDa}$ filter and the fraction below $50 \mathrm{kDa}$ was lyophilized. The EAT cells in the ascitic fluid from the previously prepared stock animal were counted and plated on 96 well plates. The first group of five was determined as the control group and the other groups were given 50-100-200 $\mu \mathrm{g} / \mathrm{mL}$ Gilaburu extract. At the end of 3,24 and $48 \mathrm{~h}$ cultured periods, the cells were counted and the number of viable and dead cells was noted. The number of dead and alive cells in control and experimental groups did not change after 3 hours period but there were $50 \%$ dead cells in experimental groups after $24 \mathrm{~h}$ culture period.
\end{abstract}

Keywords: cancer; Viburnum; EAT cell

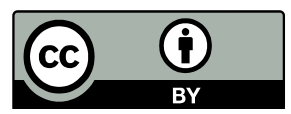

(C) 2017 by the authors. Licensee MDPI, Basel, Switzerland. This article is an open access article distributed under the terms and conditions of the Creative Commons Attribution (CC BY) license (http://creativecommons.org/licenses/by/4.0/). 